\title{
A ARTE E O NARCISISMO NA PÓS-MODERNIDADE
}

\section{ARTIGO ORIGINAL}

PIAZZA, Rosana Aparecida Dalla ${ }^{1}$, SIMIS, Ariton Omar ${ }^{2}$, AJZENBERG, Elza Maria $^{3}$ PIAZZA, Rosana Aparecida Dalla. SIMIS, Ariton Omar. AJZENBERG, Elza Maria. A arte e o narcisismo na pós-modernidade. Revista Científica Multidisciplinar Núcleo do Conhecimento. Ano. 07, Ed. 01, Vol. 06, pp. 37-54. Janeiro de 2022. ISSN: $2448-$ 0959, Link de acesso: https://www.nucleodoconhecimento.com.br/arte/o-narcisismo

Alice apanhou o leque e as luvas, e, como a sala

estava muito quente, começou a abanar-se

enquanto falava:

Ai, meu Deus! Como tudo está esquisito hoje! E

pensar que ontem tudo estava normal. Será que

eu mudei durante a noite? Vamos ver: eu era a

\footnotetext{
${ }^{1}$ Doutoranda e Mestra no Programa de Pós-Graduação em Estética e História da Arte (PGEHA-USP), Especialização em Ensino de Filosofia no Ensino Médio Universidade Federal de São Paulo- UNIFESP. Especialização em Fundamentos da Cultura e das Artes no Instituto de Artes - UNESP e graduação em Artes Visuais-Unb. ORCID: 00000003-2939-4712

${ }^{2}$ Mestrando em Estética e História de Arte - PGEHA/ USP. Possui Especialização em Docência no Ensino Superior pela Universidade SENAC, Graduação em Filosofia pela Universidade de São Paulo e Graduação em Teololgia - Faculdades EST (RS). ORCID: 0000-0002-2356-3573
}

${ }^{3}$ Orientadora. ORCID: 0000-0002-5716-6373

RC: 105695

Disponível em: https://www.nucleodoconhecimento.com.br/arte/o-narcisismo 
mesma quando me levantei esta manhã? Estou

quase me recordando que me sentia um

pouquinho diferente. Mas, se eu não sou mais a

mesma, a pergunta é "Quem afinal eu sou? Ah, aí

é que está o problema!

Lewis Carrol

\section{RESUMO}

O objetivo do artigo é demonstrar o conceito do narcisismo na pós-modernidade através da arte de Asaf Hanuca. Sob a constelação teórico-metodológica de alguns teóricos, o recorte propõe uma pesquisa bibliográfica qualitativa bibliográfica sobre o sentido epistemológico do termo narcisismo e suas metáforas no contexto na pósmodernidade dentro do ciberespaço. A partir deste quadro teórico a pesquisa se projeta nas ilustrações do artista Israelense Asaf Hanuka, conhecido pelo humor, criatividade e realismo que faz uma certa crítica ao estado das coisas no mundo pósmoderno, tendo como questão norteadora: Como os teóricos citados tratam o conceito de narcisismo na pós-modernidade e como o ilustrador Hanuka expressa esses pensamentos através da sua arte? Aproximando vozes e imagens do artista buscarse-á tratar da presença de elementos que definem, caracterizam e tangenciam a pósmodernidade narcisista. Estas questões relacionadas ao sujeito pós-moderno, como sua identidade fragmentada, continuam em debate. Partindo deste diagnóstico traçado pelos pensadores e pelas ilustrações de Hanuka, os sentidos amplificam-se, dando-nos a capacidade de observar, como em um espelho, uma sociedade doente, exausta e até mesmo paradoxal, sem fronteiras entre tempo/espaço, privado/público, com indivíduos solitários e vazios. Hanuka exprime através da sua arte o neonarcisismo em consonância com outros pensadores. Suas ilustrações expõe a

RC: 105695

Disponível em: https://www.nucleodoconhecimento.com.br/arte/o-narcisismo 
falta de senso da realidade engendrada pelos simulacros e a construção de um olhar narcísico projetado pelo mercado e reforçado pelas redes sociais.

Palavras-chave: pós-modernidade, arte contemporânea, narcisismo, Asaf Hanuka.

\section{INTRODUÇÃO}

Em um primeiro momento, tentar abordar modernidade e pós-modernidade pode parecer uma mera definição conceitual. Mas na prática está muito longe de o ser. Ao discorrer sobre esta mudança de fase na história da humanidade, que envolve processos sociais, culturais, religiosos, tecnológicos, entre outros, o narcisismo na atualidade é ponto de discussão e interesse dos mais distintos campos de saberes, sendo recentemente invocado por autores como Jean Baudrillard, Marilena Chauí, Byung Chul Han e Gilles Lipovetsky. Sobretudo, Harley (1992) aponta um caminho sobre essas questões e abordando a diferença entre o industrial e o pós-industrial do capitalismo auxiliando na compreensão da realidade pós-moderna: "Lembremos do modelo Fordista, que dá origem as grandes fábricas tornando visível as divisões sociais, a organização de classes e a luta de classes" (HARLEY, 1992, p. 118). Este modelo ancorava-se na prática de controle de todas as etapas da produção, até chegar no consumidor. Chauí (2006) também discorre sobre isso. A filósofa brasileira relata que esse modelo trouxe a ideia de qualidade e durabilidade. Em contrapartida, na fase pós-industrial imperam a fragmentação e a dispersão da produção econômica (transformando a vida da classe trabalhadora que passa a perder seus referenciais de identidade, de organização e de luta), a hegemonia do capital financeiro, a grande rotatividade de mão de obra e os produtos descartáveis (com o fim do conceito de durabilidade, tudo se torna rapidamente obsoleto). Conforme Chauí (2006), a obsolescência vertiginosa das qualificações para o trabalho, as novas tecnologias, o desemprego decorrente da automação, tudo isso alimenta a desigualdade econômica e social, dividindo a sociedade entre ricos e miseráveis. Conforme o pensamento do autor Slater (2002) a cultura da obsolescência se dá: 
(...) na experiência cotidiana a cultura do consumo vive num perpétuo ano zero de novidade, gira em torno da autocriação contínua por meio da acessibilidade às coisas que são elas próprias apresentadas como novas, a última moda, a coqueluche ou febre do momento, sempre aperfeiçoada e aperfeiçoadora (SLATER, 2002, p. 15).

Nesta direção, do consumo desenfreado, da fragmentação e da globalização da produção econômica, Harley (1992) afirma que dessas características engendram-se dois fenômenos contrários e simultâneos: de um lado existe a fragmentação e a dispersão espacial e temporal e do outro os efeitos das tecnologias e das informações.

De certa forma, com os efeitos da tecnologia tudo é reduzido em seu tempo de vida. A lógica da produção econômica é: tudo se passa aqui e agora, não há fronteiras, distancias e nem diferenças. Essa reunificação sob o espaço indiferenciado, se transforma em espaço plano de imagens fugazes, em um tempo efêmero desprovido de profundidade. Assim a revolução tecnológica fez com que desaparecesse o poder diferenciador do tempo pelo poder do instantâneo.

Vivemos no signo da instantaneidade, que impossibilitam diferenciar entre aparência e sentido, virtual e real. Pois tudo nos é dado imediatamente sob a forma da transparência temporal e espacial das aparências e apresentadas como evidências. A realidade se torna volátil e efêmera: "Se perdermos a diferenciação temporal rumamos para a "memória imediata, ou ausência da profundidade do passado, mas também perdemos a profundidade do futuro como possibilidade inscrita na ação humana" (CHAUÍ, 2006, p. 33).

Mas como fazer o homem produzir mais sem reivindicar para ele, ao menos, aquela satisfação no entretenimento e no consumo que o torna meramente alienado, inconsciente de sua condição de trabalhador explorado? O filósofo norte coreano Han (2015) afirma que o capitalismo pós-moderno já pensou nisso tudo, usando alternativas para fazer o próprio homem sentir-se útil e eficiente na sua exploração de si mesmo. A isto ele chama a transição de uma sociedade disciplinar para uma sociedade do desempenho. Han (2015, p. 34) explica que o valor do trabalho atualmente reside na capacidade de executar múltiplas funções, a qualquer tempo e RC: 105695

Disponível em: https://www.nucleodoconhecimento.com.br/arte/o-narcisismo 
com a menor quantidade de recursos possível. Afinal, o que não se faz com um smartphone conectado à internet $24 \mathrm{~h}$ ao dia?

Conforme Han (2015), a sociedade pós-moderna produz excesso de positividade resultando em excesso de estímulos e informações e desencadeando numa modificação na estrutura da economia e da atenção na vida de cada indivíduo. Essa humanidade pós-moderna é pautada na irracionalidade, totalmente voltada para o consumo desenfreado e supérfluo. Tal estilo de vida multitarefada faz com que o indivíduo não se desconecte ou se desvincule do trabalho.

Han afirma que: "esse acúmulo de tarefas alerta para um grande retrocesso na vida selvagem, o animal está obrigado a dividir sua atenção em diversas atividades" (HAN, 2015, p. 32).

Desta maneira, Han (2015) observa que o indivíduo na pós-modernidade perdeu a sua capacidade de enxergar a própria realidade, de observar-se e de ter uma visão contemplativa; de observar o seu entorno e estar alerta. Este indivíduo perdeu a capacidade de aprofundamento de si mesmo e da realidade em que está inserido, permanecendo na superfície rasa, fixando a atenção na tela do smartphone (Fig.1). Neste mesmo pensamento, Baudrillard (2005) menciona o termo "tela total". A tela do smartphone é comparada a superfície de um espelho cego.

A arte tangencia essas questões através do artista de HQs, ilustrador, escritor e professor israelense Asaf Hanuka (1974- ). Ele traduz a fascinante e obtusa vida da rotina diária da pós-modernidade e como ela nos transforma em retrato, ou melhor, em autorretrato, sem histórias grandiosas. Hanuka propõe selfies, um contador de histórias gráficas incrivelmente inteligente e cerebral. Diante destas considerações esta pesquisa busca compreender: como os teóricos citados tratam o conceito de narcisismo na pós-modernidade e como o ilustrador Hanuka expressa esses pensamentos através da sua arte? Tendo como objetivo demonstrar o conceito do narcisismo na pós-modernidade através da arte de Asaf Hanuca. 
Através das reflexões dos teóricos e em consonância com a obra de arte, esta pesquisa bibliográfica teórico-metodológica propõe um recorte sobre o aspecto epistemológico do termo narcisismo e suas metáforas no contexto da pósmodernidade dentro do ciberespaço.

\section{O NARCISISMO NA PÓS-MODERNIDADE E A ARTE DE ASAF HANUKA}

A busca pelo "bem viver" na sociedade narcisista pós-moderna cede lugar ao sobreviver. Conforme Han (2015), na tela do smartphone existe apenas a preocupação da cobrança do bom desempenho, da alta performance dos corpos vencedores malhados; não existem a tristeza e a depressão. No lugar da atenção profunda e contemplativa sobre a própria exigência autodestrutiva em que se sobrevive atualmente, há um indivíduo "dopado" que abre espaço para uma certa hipertensão de corpos e mentes já tão exaustos, conferindo um modo de vida acelerado, disperso e superficial. Neste estilo de vida quase oco a mudança instantânea equipara-se a durabilidade dos selfies expostos nas redes sociais, tornando o indivíduo intolerante ao tédio e nulo ao processo criativo. Para ser criativo é necessário ser observador profundo da realidade e nesta suspensão do tempo exige-se entrega, foco e atenção profunda.

Vejamos na (Fig. 1) cenas de Narciso pós-moderno debruçado na tela plana. Narciso é considerado o Pai do Self fatal, pois neste frenesi de registrar o momento para postar nas redes sociais muitos se distraem e acabam por sofrer acidentes, muitas vezes fatais. Com efeito, essa perda de atenção faz a sociedade humana caminhar para a vida selvagem, que realiza inúmeras tarefas ao mesmo tempo sem reflexão alguma, apenas respondendo as demandas vindas da tela.

RC: 105695

Disponível em: https://www.nucleodoconhecimento.com.br/arte/o-narcisismo 
Figura 1- Narciso- o pai da Selfie mortal.

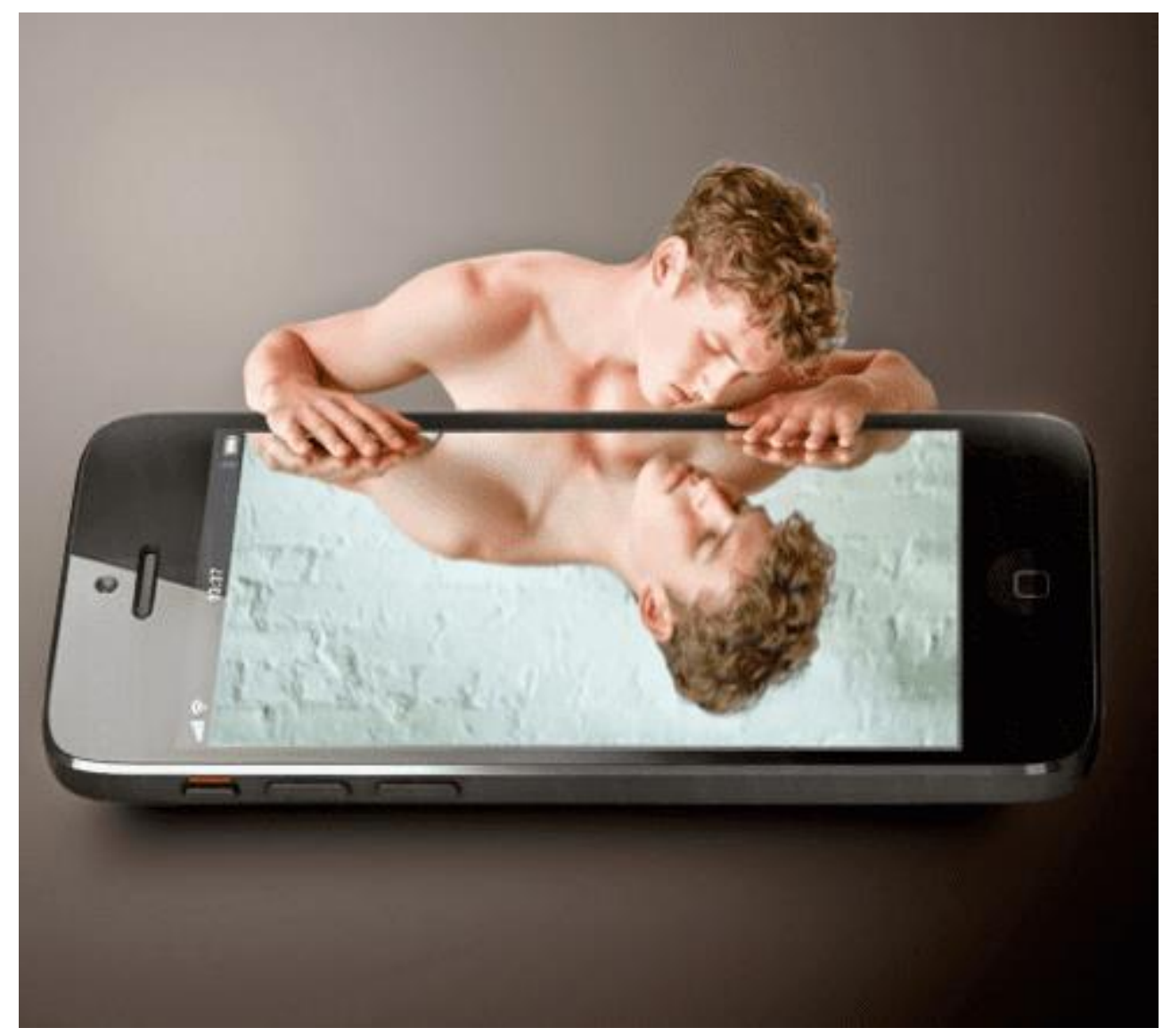

Fonte: https://poesiacronicablog.wordpress.com/2016/01/27/narciso-o-pai-da-selfiefatal/, acesso em: 07 de dez. 2018.

Neste contexto, Chauí (2006) relata a ação da mass media na realidade e na ordem do mundo limitando a vida útil e transformando insalubres essa realidade posta:

(...)1) as obras de pensamento e de arte correm vários riscos, tornamse repetitivas; 2) o trabalho de criação, torna-se eventos para o consumo; 3) de experimentação do novo, tornaram-se consagração do consagrado pela moda e pelo consumo; 4) de duradoras, tornaramse parte do mercado da moda, passageiro, efêmero, sem passado e sem futuro; 5) de formas de conhecimento que desvendam a realidade e instituem relações como o verdadeiro, tornam-se dissimulação, ilusão falsificadora, publicidade e propaganda. (CHAUÍ 2006, p. 21)

RC: 105695

Disponível em: https://www.nucleodoconhecimento.com.br/arte/o-narcisismo 
Neste prisma, a filósofa brasileira Chauí (2006) afirma que essa cultura de massa se apropria das obras culturais para consumi-las, devorá-las, destruí-las, nulificá-las em simulacros, justamente porque o espetáculo se torna simulacro e o simulacro se põe como entretenimento. A mídia transforma tudo em entretenimento (guerras, genocídios, greves, festas, catástrofes naturais, obras de arte e até obras de pensamento).

Visto que a essa destruição dos fatos, das obras e acontecimentos segue-se a lógica do consumo, da futilidade, da banalização e do simulacro, não se deve espantar que tudo isso se reduza ao fim, de forma instantânea, para uma questão pessoal de preferências, gostos, predileções, aversões, opiniões e sentimentos. Esse fenômeno é nomeado de espelho de extensão: um autorretrato; o espelho do homem da pósmodernidade. Esse espelho se propaga sobre a rede. A mídia é o senso comum cristalizado que a indústria cultural desenvolve com cara de coisa nova.

Chauí (2006, p. 30) assinala que a "atrofia da imaginação e da espontaneidade do consumidor cultural" deve ser explicada não como fenômeno da psicologia, pois os próprios produtos paralisam aquelas faculdades. Essa estratégia que impede a rápida percepção mental do espectador é bloqueada efetivamente porque ele deveria ser rápido para não perder os fatos que se desenrolam a sua frente.

Han (2015, p. 33) percebe o tédio profundo como: "pássaro onírico, que choca o ovo da experiência". E acrescenta:

(...) Pode-se dizer que o ninho do repouso se perde pouco a pouco na modernidade. Não há espaço para o descanso e a sociedade está doente, pois a falta de repouso resulta no desaparecimento dos dons de ver, escutar, falar, pensar e escrever. E para tanto é preciso atenção profunda, e isso exige que o ser humano mergulhe nas coisas (HAN 2015, p. 33).

É necessário que Narciso mergulhe no lago da sua própria consciência. É preciso disposição para a atividade. Han (2015, p. 37) faz um apelo a sociedade pós-moderna: 
"Caso o elemento contemplativo seja expulso, a vida humana findará em uma hiperatividade mortal: por falta de repouso, nossa civilização caminha para a barbárie".

Lipovetsky (2005) endossa a teoria de Han (2015) e Chauí (2006) revelando outras mazelas sociais da pós-modernidade. Neste sentido, Lipovetsky (2005, p. 156) afirma que vivemos para nós mesmos, sem nos preocuparmos com nossas tradições e com nossa posteridade; o sentido histórico foi abandonado da mesma forma que os valores e as instituições sociais. Basta observarmos o terrorismo internacional, a crise econômica, a escassez de matérias-primas, a volta da angústia nuclear, os desastres ecológicos, que criaram uma crise nos líderes políticos. O medo de uma catástrofe eminente explica o desenvolvimento das estratégicas narcísicas de sobrevida que prometem a saúde física e psicológica; como o futuro se apresenta ameaçador e incerto, então resta debruçar-se no presente, onde não resta tempo e espaço para se organizar permanecendo numa juventude sem fim; a busca do hedonismo total nos remete sempre a essa tela plana, onde o real se estabelece. Nesta sociedade do desempenho e do cansaço, da banalização social e da neutralização a vida privada é que sai vitoriosa nesta maré de apatia. O cuidar da saúde, preservar a própria estabilidade material, esperar pelas férias merecidas: o foco está sempre no eu.

De acordo com Han, que reitera o pensamento de Chauí (2006):

É preciso aprender a ver. Para aprender a ver é preciso pausa, é preciso tempo para se contemplar a vida e as coisas que estão à volta. Aprender a contemplar, conhecer a si, e conhecer o outro, para assim conhecer as virtudes do outro, aprender com alteridade do olhar (HAN, 2015, p. 51).

E é isso que a sociedade da positividade e do desempenho elimina, anula, não há espaço para as diferenças em uma sociedade homogenia. A falta de negatividade, diversidades e pluralidades impede o olhar para o outro, tornando-se nulo, transparente e, assim, perdemos a alteridade. A humanidade torna-se maquinal, subordinada aos interesses consumistas e lucrativos. Sobretudo, afirma Han (2015): 
(...) o excesso de positivação geral do mundo, transforma o homem como também a sociedade em máquina de desempenho. E esse esforço exagerado de maximizar o desempenho. (...) afasta toda a negatividade e enfraquecimento da natureza humana (HAN, 2015, p. 54).

Polêmicas e contradições à parte, a pós-modernidade apresenta-se como uma estrada, um percurso em que se transbordam novas ideias e pensamento. Não se sabe qual é o seu destino final. Mas temos pistas contundentes do que estamos nos tornando até esse momento.

Narciso é um mito muito difundido na Psicologia, Psicanálise, no campo das Artes e Literatura. Narcisismo é uma expressão polissêmica e essa definição apresentou-se como a mais coerente após todas as leituras e abordagens no decorrer desta pesquisa. E, diante desta situação, se faz necessário relatar o mito de maneira concisa por motivos óbvios. Narciso é um mito grego que narra sobre um lindo jovem que se encanta com sua própria imagem refletida no lago e na tentativa de agarrar seu próprio reflexo ele se afoga. O narcisismo como uma metáfora humana é dotado de muitas significações, como vaidade, autoadmiração, egoísmo, egocentrismo e hedonismo.

O neologismo "neonarcisismo" foi criado por Lipovetsky (2006) dentro do contexto da pós-modernidade. Neste contexto, o "novo Narciso" se apaixona por uma tela plana e não mais por seu próprio reflexo no lago. Como bem-visto, o novo Narciso não se vê. A imagem refletida não remete a seu duplo, autoimagem, mas sim ao que ele enxerga nesta tela plana. O que ele contempla são estímulos, seduções e apelações para promover o consumo de mercadorias, ou seja, o narciso que olha para tela plana responde aos estímulos criados pelo canto da "sereia mercado".

Para Chauí (2006, p. 41), o termo "sereia do mercado" se dá com a discussão sobre o simulacro, onde o poder exercido pela mídia e forças do capital (marketing e consumo) vai além da concepção de uma não fixação da identidade como sujeito crítico pensante. Para a filósofa, a propaganda precisa acompanhar esse ritmo da sociedade pós-moderna onde tudo é veloz, fugaz, efêmero e desaparece do dia para a noite. Desta forma, o "canto da sereia" conhecido como mercado/mídia desenvolve RC: 105695

Disponível em: https://www.nucleodoconhecimento.com.br/arte/o-narcisismo 
com eficácia a ideia de que se estabelece sob a necessidade de inventar novos desejos e manipulá-los para o consumo de produtos sempre novos e fugazes, criando um consumo em cadeia, constante e infinito.

Dentro da perspectiva das artes, há uma nova série de ilustrações do artista Israelense Asaf Hanuka (1974-) que vislumbra o mundo por outro ângulo, percebendo como as redes sociais, a vida do dia a dia, a busca pela ambição, o narcisismo social e desigualdades sociais podem afastar as pessoas das coisas mais importantes de suas vidas, como a família, a contemplação e a reflexão sobre si e sobre o mundo. Ele é conhecido por suas ilustrações criativas que criticam esse mundo (Fig. 2) pósmoderno dos excessos e consumo desenfreado.

Figura 2: llustração de Asaf Hanuka, Submundo, 2017.

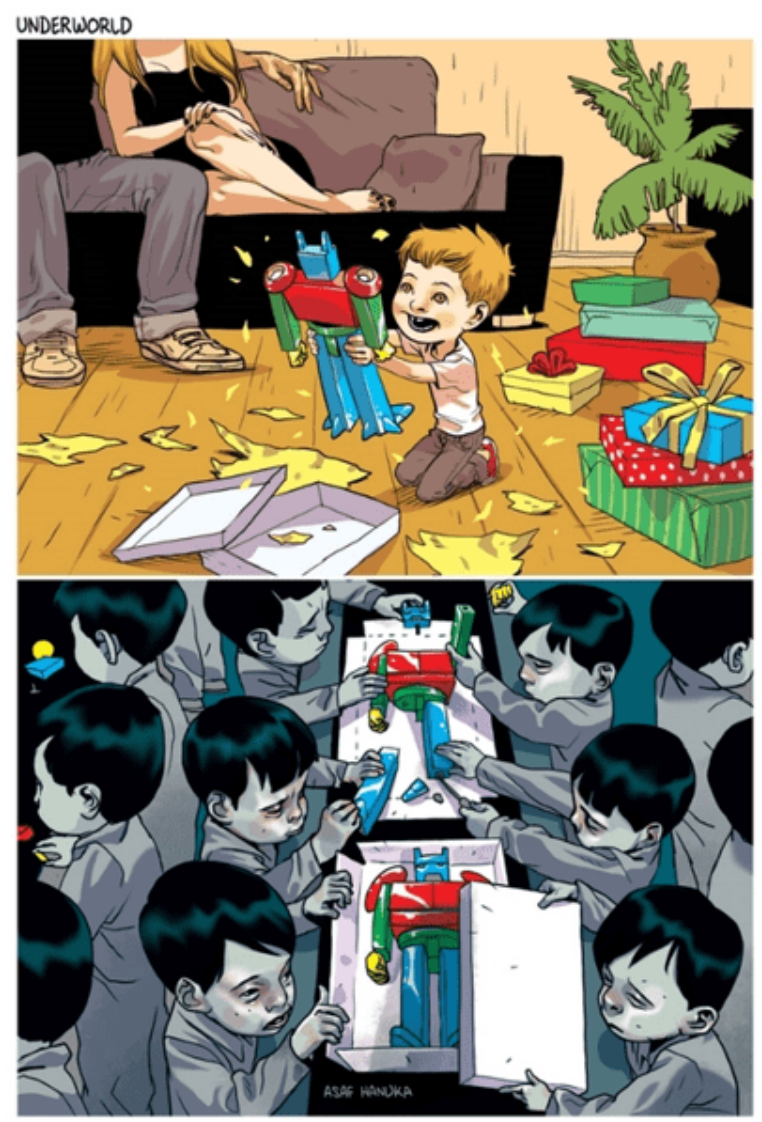

Fonte: http://www.asafhanuka.com/underground/, acesso em 29 dez. 2021.

RC: 105695

Disponível em: https://www.nucleodoconhecimento.com.br/arte/o-narcisismo 
No que tange as questões sobre o narcisismo, a falta de senso da realidade e dos excessos de positividade a (Fig. 3) mostram a autoimagem de um homem que possui uma autoestima alta, uma certa síndrome de superman. Afinal, hoje, a sociedade é bombardeada pelos mitos dos super-heróis, filmes e series que retratam o homem como um ser sobre-humano.

Mas o que se pode afirmar é que o llustrador busca discutir a verdadeira persona do super-homem. O herói dos dias atuais são os pais e mães que trilham uma jornada dupla para criar os filhos, manter uma casa e "ainda ter tempo de se entreter, ser belo, atraente e atualizado na sociedade do desempenho e da positividade" afirma, Han (2015, p. 53).

Figura 3- Asaf Hanuka. Universo Paralelo, 2017.

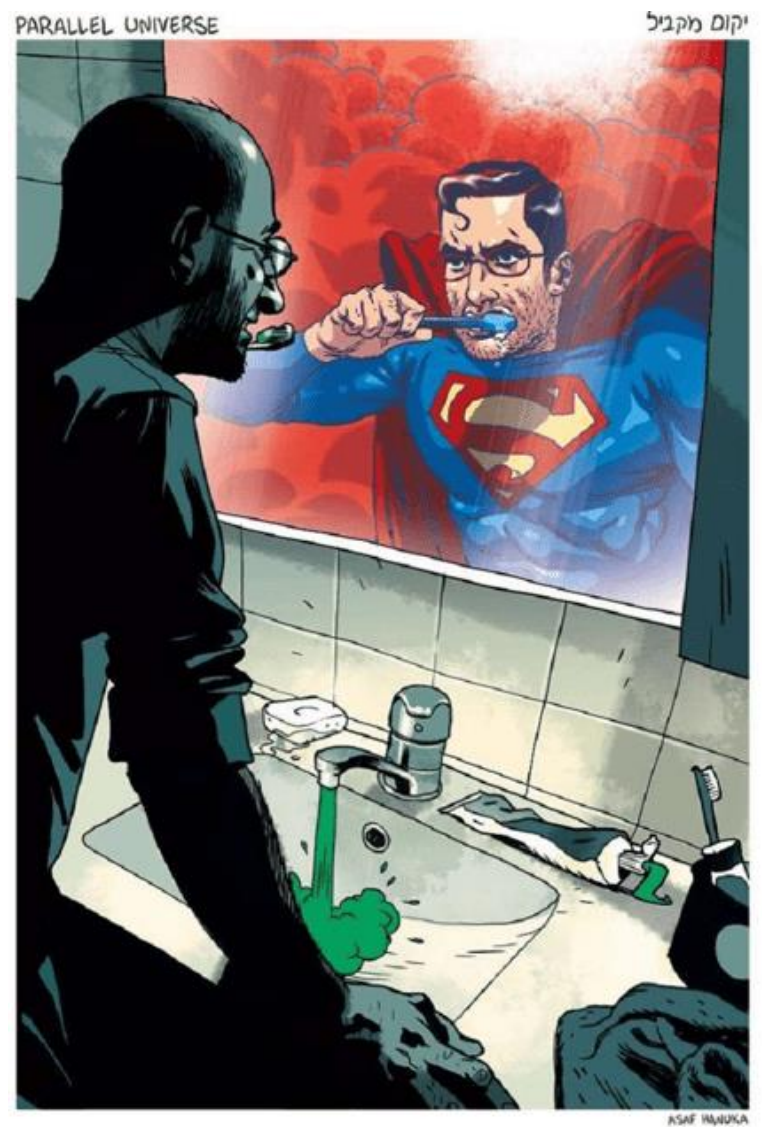

Fonte: https://alchetron.com/Asaf-Hanuka, acesso em 29 dez. 2021.

RC: 105695

Disponível em: https://www.nucleodoconhecimento.com.br/arte/o-narcisismo 
$\mathrm{Na}$ (Fig. 4), cujo título Likecolic (2017), temos um neologismo que mistura a palavra Like (gostar, curtir) e Alcoholic (alcoólico), satirizando uma característica viciante da utilização de redes sociais digitais. Uma cena bem típica da pós-modernidade, além da exposição do compartilhar, ser visto, olhado admirado, torna-se um vício na busca de saciar o desejo de ser alguém especial e invejado, mesmo que essa exibição dure alguns minutos. O número de 'likes' é uma validação que não apenas angaria valor afetivo para si, mas desperta sensações corporais emocionais, hedonismo, prazer, sedução e sucesso na propagação da postagem.

Figura 4- Asaf Hanuka. Likecoholic, 2017.

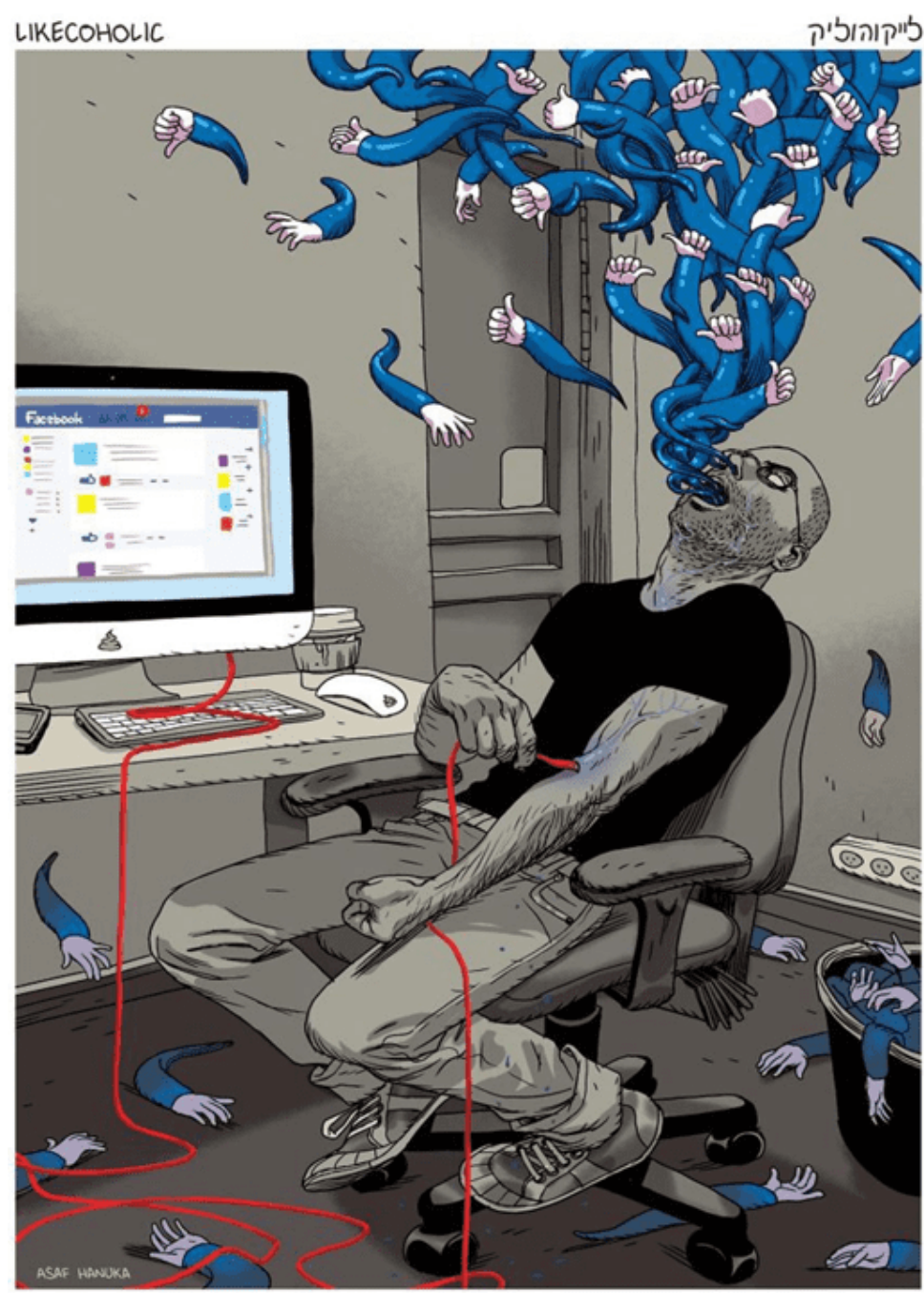

Fonte: http://www.asafhanuka.com/likecoholic/,acesso em 29 dez. 2021.

RC: 105695

Disponível em: https://www.nucleodoconhecimento.com.br/arte/o-narcisismo 
Para Lipovetsky (2006, p. 102), o consumidor reduz a difusão de bens de conforto, criando uma cultura cotidiana dominada pela mitologia da felicidade privada e pelos ideais hedonistas. Segundo ele, a nossa sociedade do objeto apresenta-se como a civilização do desejo, prestando um culto ao bem-estar material e aos prazeres imediatos. Como é revelada na (Fig.5), comprar ou não comprar?

Figura 5- Asaf Hanuka. To buy or not to buy, 2017.

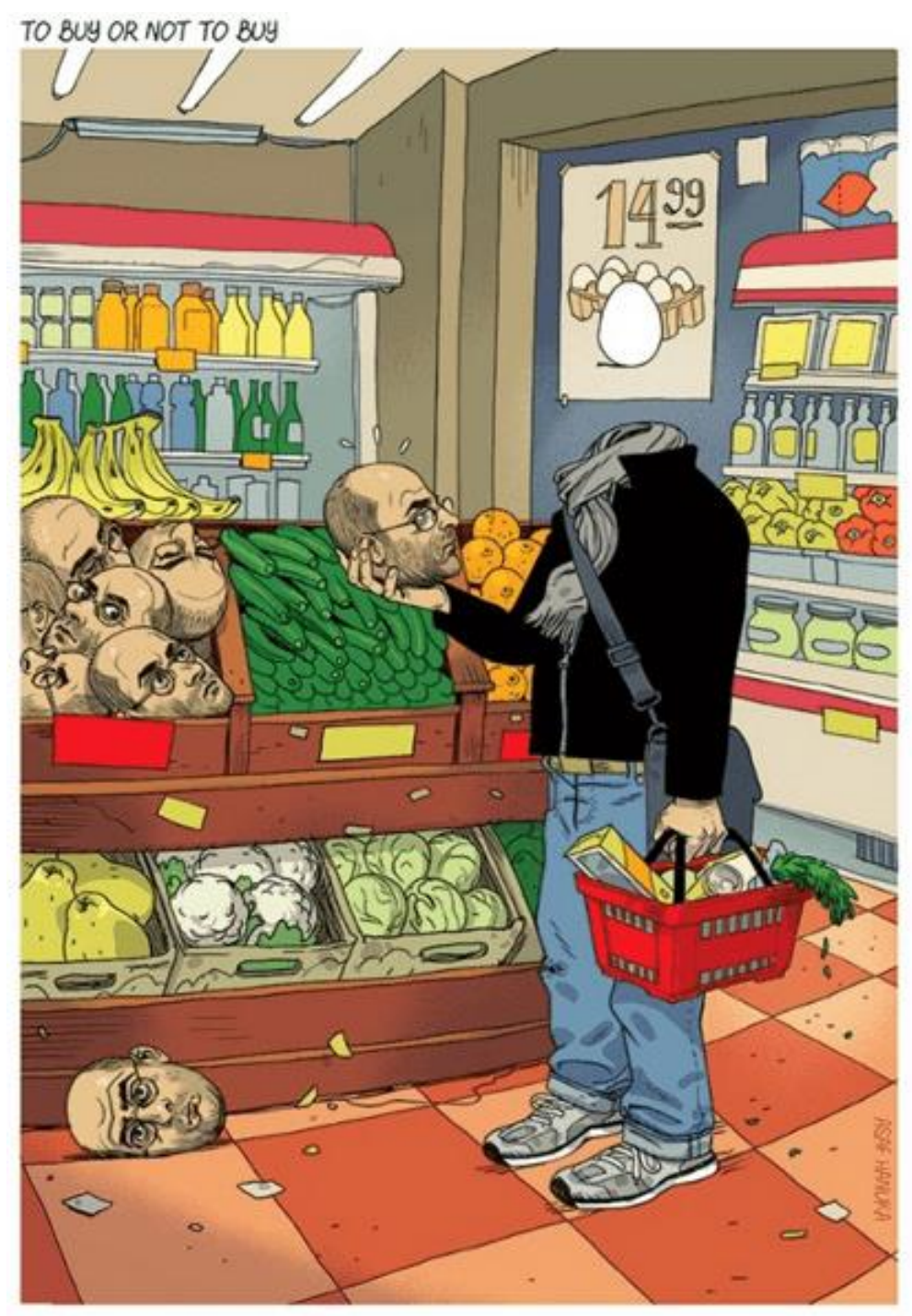

Fonte: http://www.asafhanuka.com/the-realist-2/,acesso em 17 dez. 2018.

RC: 105695

Disponível em: https://www.nucleodoconhecimento.com.br/arte/o-narcisismo 
Por todo canto exibem-se as alegrias do consumo, é como uma paixão desenfreada, bem parecida com aquela que Narciso teve ao se olhar. É como se estivessem ressoando os hinos dos prazeres, dos lazeres e às férias. Tudo seduz, salta aos olhos, tudo se vende com promessas de felicidade individual. Narciso é tomado pela sua própria imagem, contudo não há racionalidade, autoconsciência, apenas instinto pulsante pelo desejo de ter, possuir o objeto.

Diante do viver melhor, "aproveitar a vida", gozar do conforto e das novidades mercantis aparecem os direitos do indivíduo, fins em si, preocupações cotidianas de massa. Nesta cultura que convida a apreciar os prazeres do instante, bem como a desfrutar a felicidade aqui e agora, a viver para si mesmo, a transfigurar-se em uma quase seita do Novo Evangelho: "Comprem, gozem, essa é a verdade sem tirar nem pôr" (LIPOVETSKY, 2006, p. 152).

Para Lipovetsky (2006), na sociedade de consumo, a ambição é liberar o princípio do gozo, desprender o homem de todo um passado de carência, de inibição e de ascetismo. Não há mais injunções disciplinares nem rigoristas. Para ele, o que existe é a tentação dos desejos materiais, a celebração dos lazeres e do consumo, o sortilégio perpétuo das felicidades privadas.

Desta maneira este indivíduo desligado ou alienado como cita Chauí (2006), se mostra muitas vezes incapaz de resistir aos "cantos da sereia" quanto aos seus impulsos internos. "Assim, somos testemunhas de todo um conjunto de comportamentos e consumos patológicos e impulsivos", acrescenta Han (2015. p. 45). 
Figura 6- Asaf Hanuka. Emojinal, 2017.
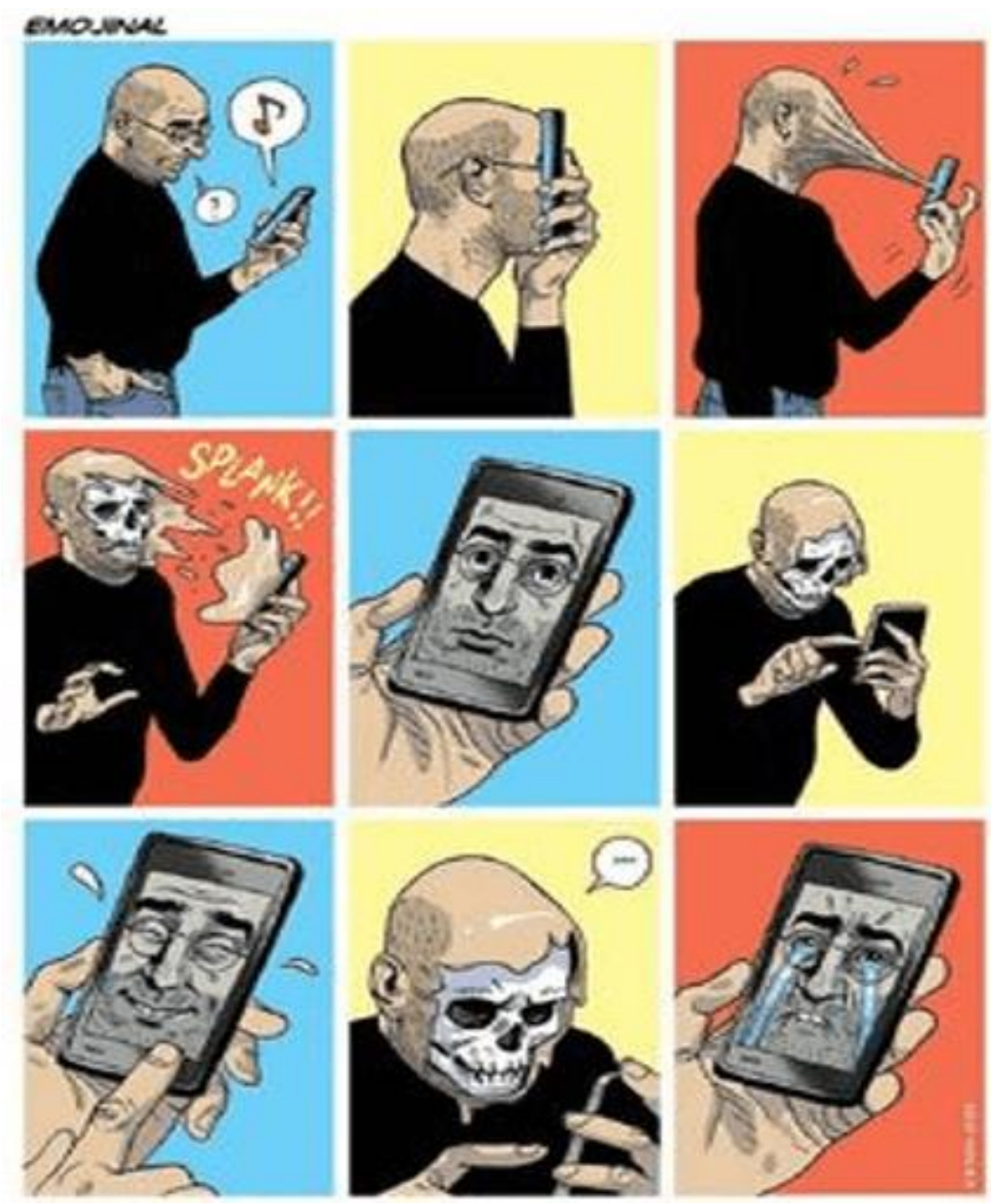

Fonte: https://www.pinterest.pt/pin/107875353562428227/, acesso em 17 dez. 2018.

Conforme a imagem (Fig. 6), Hanuka se auto representa em 9 quadros. O princípio da destruição da própria liberdade e existência começa com o som emitido pelo smartphone avisando da chegada de uma mensagem, talvez do WhatsApp, uma dança coreografada e ensaiada no tik tok; não se sabe ao certo qual o aplicativo. A conversa se desenvolve sob o suporte das faces arrancadas simbolicamente. Dando a ideia da transferência dos sentimentos e emoções em formato de emoji[4]. Essas carinhas coloridas são imagens que na comunicação ciberespaço só são possíveis de serem eficientes e sintetizadas com imagens que simulem as sensações e emoções

RC: 105695

Disponível em: https://www.nucleodoconhecimento.com.br/arte/o-narcisismo 
entre um emissor e receptor. Segundo Baudrillard (1991), as imagens na tela total são apreendidas como "hiper-reais", ou seja, "mais real que real". Por isso, todo acontecimento, qualquer lugar, precisa ser fotografado, registrado pela tela do smartphone, inclusive as reações faciais de forma precisam, nada fica em oculto, ao mesmo tempo que os filtros antienvelhecimento deve ser ativados produzindo simulacros agradáveis a todos os consumidores. Assim existe a necessidade de transpor exatamente suas emoções através de imagens, simulacros que representem o próprio sujeito. Claro que esse sujeito fotografado é apenas um personagem que forja uma vida feliz e perfeita, entrelaçando-se a essa positividade tóxica e sem sentido.

\section{CONSIDERAÇÕES FINAIS}

Considerou-se neste recorte que o ilustrador Hanuka expressou-se através da sua arte, apresentando o neonarcisismo em consonâncias com os pensamentos de Baudrillard, Lipovetsky, Han e Chauí em certos aspectos.

Hanuka retoma Baudrillard (1991, p. 178-198) em suas ilustrações e apresentando a ausência do mistério das imagens, das sensações, emoções, enfim, a ausência do segredo do outro lado da tela que se transforma na hipervisibilidade (ou hiper-real).

Hanuka (1974- ) produz simulacros, considerados imagens de um "mundo sem falhas". O simulacro torna-se algo fascinante na pós-modernidade porque a imagem é reduzida a materialidade do significante buscando a intensidade sensorial e pouco reflexiva. Hanuka e Baudrillard (1991) mostram que através destes jogos multimidiáticos o narcisismo se transforma em paixão niilista da virtualidade no lugar da realidade.

Hanuka interpela para a substituição da face, da interação de corpo presente para um corpo ausente, onde o simulacro representa exatamente o que o emissor está querendo dizer, feito uma máquina com sentimentos artificiais. No contexto da sociedade pós-moderna quase tudo se transforma em espetáculo midiático e

RC: 105695

Disponível em: https://www.nucleodoconhecimento.com.br/arte/o-narcisismo 
plastificado para cumprir o papel de simular, representar tal realidade artificial e mascarada. Assim como Chauí (2006), Han (2015) e Lipovetsky (2006) criticam tal lógica do mercado de iludir com sonhos falsos, sem se importar com os prejuízos da saúde emocional do indivíduo que consome na busca de apaziguar esse vazio que nunca é preenchido.

Parar para contemplar o mundo perdeu o sentido. Desaprendemos a ver o mundo na pós-modernidade. A necessidade hoje é de que não há momento de contemplação e reflexão. O ser humano deve apenas atender as demandas da tela, comprar, consumir, desejar cada vez mais o sonho que explode a cada segundo na telinha que promete uma vida cheia de arco-íris com seus unicórnios fantásticos. A realidade fora da tela é proibida, cinza, sem perspectiva para a contemplação, sem ação, apenas uma positividade tóxica numa espécie de transe inconsciente. O real e a racionalidade devem ser negados, desprezados e anulados por essa positividade toxica.

De acordo com Baudrillard (1991) a tela é o lugar de uma sedução fria, onde perpassam os encantos narcísicos da pós-modernidade. O indivíduo vive na era tecnológica, na qual o celular é quase uma extensão do corpo humano. Além de ser uma extensão do corpo físico, a virtualidade toma o lugar do real em certo grau. $\mathrm{O}$ indivíduo pós-moderno projeta seu ego narcísico através de uma imagem criada por seus desejos de consumir. O indivíduo passa a existir mais na rede social onde essas projeções sonhadas são alcançadas como uma necessidade vital. Na tela do smartphone o indivíduo se projeta jovem, belo, bem-sucedido, amado, admirado nem que seja por alguns minutos. A admiração e a aprovação dada pelos likes são viciantes, como mostra o artista Hanuka.

Sobretudo, a lógica do mercado da pós-modernidade estimula o narcisismo, desenvolvendo várias distopias e produzindo a necessidade quase vital no indivíduo de se expor nas redes sociais. Considerando que o virtual passou a tomar o lugar do real em grande parte da vida na pós-moderna, as redes viraram uma necessidade fundamental e o sujeito é passível de ter um comportamento narcísico através da 
identificação com uma imagem projetada pelo ego. Existe uma nova subjetivação na construção da identidade humana e um novo interagir no mundo.

Assim, a pós-modernidade apresenta um narcisismo sem identidade, representada no espelho/tela plana. Esse narciso está apaixonado por simulacros criados pelo ciberespaço. As paixões de Narciso são seus desejos pulsantes em forma de objetos que se compram no shopping. Este novo Narciso pós-moderno devora os seus sonhos de consumo que duram pouquíssimo tempo e logo se desperta com a fome de um ciclope voraz por mais novidades do mercado.

Esta sociedade de consumo desencadeia o excesso e o descontrole de si: compras compulsivas, superendividamento das famílias, "fanáticos" por jogos de vídeo, ciber dependentes, toxicomanias, práticas viciosas de todos os tipos, anarquia dos comportamentos alimentares como bulimias, busca por eterna juventude e obesidades. Esse individualismo desenfreado e caótico do consumidor, afeito ao relaxamento dos controles coletivos, às normas hedonistas, à escolha da primeira qualidade é resultado de uma educação liberal que contribuiu para compor um indivíduo desligado das necessidades coletivas e comuns. Por toda a parte se vê a tendência ao desregramento e a vertigem de si próprios entregues ao supermercado contemporâneo dos modos de "vida felizes".

Lipovetsky (2007), alerta que na medida que se amplia o princípio de pleno poder sobre a direção da própria vida, as manifestações de dependência e de impotência subjetivas se desenvolvem num ritmo crescente.

\section{REFERÊNCIAS}

BAUDRILLARD, J. Simulacros e simulação. Tradução: Maria João da Costa Pereira. Lisboa: Relógio d'água, 1991.

Tela total, mitos e ironias do virtual e da imagem. Porto Alegre:

Sulina, 2005.

RC: 105695

Disponível em: https://www.nucleodoconhecimento.com.br/arte/o-narcisismo 
CHAUÍ, Marilene. Simulacro e poder. Uma análise da mídia. São Paulo: Fundação Perseu Abramo, 2006.

HAN, Byung Chul. A Sociedade do Cansaço. Tradução de Enio Paulo Giachini. Rio de Janeiro: Vozes, 2015.

HARLEY, David. A condição pós-moderna. São Paulo: Loyola, 1992.

LIPOVETSKY. Gilles. A felicidade paradoxal. Ensaio sobre a sociedade de hiperconsumo. São Paulo: Companhia das Letras, 2007.

A Era do Vazio: um ensaio sobre 0 individualismo contemporâneo. São Paulo: Manole, 2005.

SLATER, D. Cultura do consumo \& modernidade. São Paulo: Nobel, 2002.

\section{APÊNDICE- REFERÊNCIA NOTA DE RODAPÉ}

4. Emoji- consiste em imagens com expressões de desenho animado.

Enviado: Abril, 2021.

Aprovado: Janeiro, 2022.

RC: 105695 